\title{
Etterlatte etter selvmord har behov for profesjonell hjelp
}

\section{Det er utfordrende for etterlatte etter selvmord å ta} kontakt med hjelpeapparatet. Det er derfor nødvendig med et støtteapparat som ivaretar deres behov på en best mulig måte.

Camilla Nyseter

Sykepleierstudent

Avdeling for helse- og sosialfag, Høgskolen i Molde

Ingeborg Røv

Sykepleierstudent

Avdeling for helse- og sosialfag, Høgskolen i Molde

Trude Fløystad Eines

Dosent

Avdeling for helse- og sosialfag, Høgskolen i Molde

\begin{tabular}{lll|}
\hline Angst Beredskap Litteraturstudie Psykisk lidelse & Samarbeid \\
\hline
\end{tabular}

\section{Hovedbudskap}

I Norge ble det registrert 674 selvmord i 2018. Når en person tar sitt eget liv, berører det både den nærmeste familien og venner som har en relasjon til den avdøde. Etterlatte som har mistet noen i selvmord, har høyere risiko for å utvikle depresjon, og de kjenner ofte på skyld, skam og stigma. Mange etterlatte etter selvmord har behov for profesjonell hjelp i varierende grad. 
Det er årlig rundt 800000 mennesker i verden som tar livet sitt (1). Selvmordstallene er høyest i land med gode inntekter. Selvmord er den nest vanligste dødsårsaken blant unge i verden.

I Norge ble det i 2018 registrert 674 selvmord i Norge -202 kvinner og 472 menn (2). Hvis man regner ti etterlatte per selvmord, vil det si at rundt 6-7000 etterlatte vil bli berørt hvert år bare i Norge $(2,3)$.

Se statistikk om selvmord i Norge her.

Selvmord er en av de største helsemessige utfordringene vi har i vår tid. Det er forbundet med omfattende personlige og samfunnsmessige problemer for de som tar livet sitt, de som fors $\varnothing$ ker å ta livet sitt, og de som berøres som etterlatte.

De etterlatte kan omfatte den nærmeste familien, men også venner, besteforeldre, medpasienter, terapeuter, helsepersonell og kolleger som føler at de har hatt en nær relasjon til den avdøde (4).

\section{$\equiv$ «Sosial stigmatisering er en vedvarende del av sorgerfaringene til etterlatte.»}

Mange etterlatte etter selvmord sitter igjen med en følelse av skyld og skam og prøver å finne en årsak til dødsfallet. Sosial stigmatisering er også en vedvarende del av sorgerfaringene til etterlatte, og det kan bidra til at sorgarbeidet blir vanskeligere og forlenget (5).

Hensikten med denne litteraturstudien var å beskrive etterlattes erfaringer etter selvmord.

\section{Metode}

En litteraturstudie innebærer å søke systematisk, kritisk vurdere og presentere forskning innen et valgt emne (6). Denne litteraturstudien er basert på ti kvalitative forskningsartikler.

Vi gjennomf $\varnothing$ rte $s \varnothing \mathrm{k}$ i databasene PsycINFO og CINAHL i perioden februar-mars 2020 med bruk av søkeordene suicide, family, bereaved, parent, relative, next of kin, spouses og experience.

Vi hadde følgende inklusjonskriterier: 
- Forskningsartiklene skulle være publisert i tidsrommet 2010-2020.

- Deltakerne i studiene skulle være voksne over 18 år.

- Studiene i artiklene skulle ha benyttet et kvalitativt design.

- Deltakerne i studiene skulle være pårørende eller etterlatte.

Databases $\varnothing$ kene resulterte i 15 vitenskapelige artikler, som vi kvalitetsvurderte med bruk av sjekklister for å vurdere kvalitative forskningsartikler (7). Det innebærer blant annet å vurdere resultatenes gyldighet, metodisk kvalitet, pålitelighet og overførbarhet (8).

Vi ekskluderte fem av artiklene fordi de hadde benyttet et kvantitativt design som ikke var egnet til å besvare litteraturstudiens hensikt, eller at etiske hensyn ikke var tilstrekkelig ivaretatt eller beskrevet.

Videre analyserte vi funn fra de ti inkluderte artiklene med utgangspunkt i Evans' (9) teori for innholdsanalyse, som resulterte i tre ulike hovedtemaer (se figur 1).

Figur 1. Presentasjon av litteraturstudiens tematiserte hovedfunn

\section{Resultater}

\section{Det var utfordrende å be om hjelp}

Det var utfordrende for de etterlatte å ta kontakt med helsepersonell og be om hjelp etter selvmordet. De hadde behov for å bli ivaretatt av noen som viste medfølelse, og som hadde erfaring med å følge opp etterlatte ved selvmord.

Fordi mange av de etterlatte slet med søvnvansker, sinne, dårlig matlyst, angst, sjokk, depresjon og selvmordstanker, var de ikke i stand til å be om profesjonell hjelp. De ønsket derfor å bli kontaktet av støtteapparatet istedenfor å måtte ta initiativ selv (10-15). 
De fleste av de etterlatte fikk st $\varnothing$ tte fra politiet, rådgivere, sykepleiere, psykologer og leger. Mange av dem fikk god st $\varnothing$ tte og hjelp fra familie, venner eller andre selvmordsetterlatte $(10,11,13)$. Likevel hadde mange behov for støtte og oppfølging av helsepersonell.

\section{$\equiv$ «Flere følte at helsepersonellet ikke klarte å gi dem den støtten de forventet.»}

Flere følte at helsepersonellet ikke klarte å gi dem den støtten de forventet, og at helsepersonellet hadde stigmatiserende holdninger til selvmord med en respektløs, nedlatende og fordomsfull tilnærming (10, 11, 13, 16, 17).

Ofte måtte de etterlatte forholde seg til ulikt helsepersonell, noe som førte til at de måtte gjenfortelle historien sin flere ganger. Det var utfordrende for mange $(10,12,13,18)$.

Når helsepersonellet selv var usikre i dialogen med de etterlatte, ble foreldrene til de avdøde mer hjelpeløse og usikre på hvor eller hvordan de skulle søke hjelp $(11,12)$. Likevel ble sykepleieren løftet frem som omsorgsfull og st $\varnothing$ ttende i sorgprosessen $(10,12,13)$.

\section{Mange følte seg alene med sorgen}

Mange av de etterlatte fortalte at de unngikk å snakke om selvmordet med andre på grunn av smerten og sorgen de bar på, og at de ikke ønsket å belaste andre med tankene sine. Andre følte at de selv måtte være sterke for å ivareta familiemedlemmer i sorg $(14-17,19)$.

De satte sine egne behov til side, og mange følte seg alene i sorgen $(14-17,19)$. Noen foreldre erfarte at selvmordet påvirket forholdet de hadde til sine gjenlevende barn, og at de ikke klarte å være til stede for dem på grunn av sorgen og smerten de kjente på (14).

Flere av de etterlatte beskrev at stigmatisering var en av grunnene til at de ikke ønsket å snakke om dødsfallet med andre. Andres avvisende atferd bidro i tillegg til at de følte seg tilsidesatt og isolert, og mange erfarte å miste kontakten med venner. 
De følte også at andre i samfunnet hadde liten forståelse for sorgen de gikk igjennom (11, 13, 16-19). Funn i

litteraturstudien viser likevel at noen etterlatte følte at de fikk god st $\varnothing t t e$ fra ektefelle, venner, kolleger, familie og naboer $(11,13,15)$.

De etterlatte følte seg heldige som kunne snakke åpent og dele sine følelser med sine nærmeste, noe som hjalp dem i sorgarbeidet $(13,15)$. Mange etterlatte fikk hjelp med praktiske ting i hverdagen, som husarbeid, matlaging og betaling av regninger $(13,19)$.

\section{Støttegruppene ga dem håp}

De som hadde mistet noen i selvmord, fortalte at det hjalp å snakke med andre som hadde opplevd det samme. Det bidro til at de ikke følte seg alene i sorgen. Deltakelse i st $\varnothing$ ttegrupper ble derfor et sted hvor de kunne dele sine erfaringer, følelser og smerte uten å være redd for andres reaksjoner $(10-13,15,19)$.

Støttegruppene hadde en viktig funksjon for de etterlatte når det gjaldt å bygge seg opp igjen og gi dem håp om at ting skulle bli bedre etter hvert. Ved å snakke med andre som var i forskjellige stadier i sorgprosessen, fikk de muligheten til å anerkjenne sin egen måte å mestre sorgen på $(10-12,15,19)$.

\section{三 «Noen deltakere var skeptiske til å delta i en støttegruppe. De hadde ikke tro på at det ville hjelpe dem.»}

Noen deltakere var skeptiske til å delta i en støttegruppe. De hadde ikke tro på at det ville hjelpe dem med å mestre sorgen. De følte at støttegruppene var lite produktive, og at de manglet ledere som hadde tilstrekkelig kompetanse om for eksempel ulike mestringsstrategier (10).

Flere etterlatte hadde erfart at støttegrupper ikke bare handlet om å snakke om deres egne opplevelser, men at de også måtte lytte til andres historier om smerte og sorg. Det var veldig krevende for mange av dem, spesielt i den første tiden etter å ha mistet noen i selvmord $(10,19)$. 


\section{Diskusjon}

\section{Etterlatte trenger helhetlig omsorg $\mathrm{i}$ tiden etter selvmordet}

Litteraturstudiens funn viser at det er utfordrende for etterlatte å ta kontakt med helsepersonell etter selvmordet, og at det derfor er behov for et st $\varnothing$ tteapparat som ivaretar deres behov bedre.

Ifølge Dyregrov, Plyhn og Dieserud (20) kan det skyldes at de ikke er i stand til å be om den hjelpen de trenger, eller at de ikke er i stand til å definere sine egne behov i den krevende situasjonen. En krise kan føre til sterke emosjonelle reaksjoner, som ofte bidrar til at de i en periode ikke mestrer dagliglivet (21).

Litteraturstudien viser videre hvordan sorgen etter et selvmord påvirker etterlattes fysiske og psykiske helse. For å ivareta etterlattes grunnleggende behov bør helsepersonell ha god kunnskap om og erfaring med sorg og hvordan de bør støtte etterlatte etter selvmord (20).

Ifølge helsepersonelloven $\$ 4$ (22) skal helsepersonell utføre arbeidet på en faglig forsvarlig måte og gi omsorgsfull hjelp ut ifra sine kvalifikasjoner, situasjonen de befinner seg i, og arbeidets karakter.

For sykepleieren er det viktig å kjenne til pasientens opplevelse av sin egen situasjon. I en fase der den etterlatte kjenner på sinne, bitterhet og håpløshet, er det viktig at sykepleieren griper inn for å forebygge at situasjonen forverrer seg ytterligere (23).

Gode erfaringer i møte med hjelpeapparatet kan ha stor betydning for de etterlatte over lang tid, mens dårlige erfaringer kan gjøre vondt i mange år (20). God kompetanse på riktig nivå og på riktig sted er en forutsetning for gode, effektive og trygge tjenester (24).

\section{Sykepleiere bør motivere til åpenhet}

Denne litteraturstudien viser at etterlatte følte at det var vanskelig å snakke om sorgen til andre, og at det var utfordrende å be om hjelp. Det støttes av Kristoffersen, Nordtvedt og Skaug (25), som påpeker at det er vanskelig å snakke når man befinner seg midt i sorgen. 
Noen bruker det å la være å snakke om sorgen som en mestringsstrategi (20). En sykepleier bør kunne gi den etterlatte mulighet til å uttrykke sin sorg og legge vekt på anerkjennelse, normalisering og validering av følelser.

Det er viktig å møte de etterlatte der de er og avhjelpe deres behov. Personlige egenskaper hos sykepleieren er avgjørende for å skape en god relasjon til etterlatte som har opplevd en traumatiserende hendelse $(23,25)$.

Litteraturstudiens funn viser at mange etterlatte unngikk å snakke med familie og venner fordi de ikke ville være en belastning for dem. De ønsket å være sterke og noen som andre kunne støtte seg på i den vanskelige tiden. Det var derfor vanskelig for dem å vise følelser - til og med i deres eget hjem.

Familiens samhold, indre dynamikk og kommunikasjon og familiemedlemmenes muligheter til å bearbeide sorgen kan bli påvirket negativt dersom fakta om dødsfallet holdes skjult for noen av familiens medlemmer (3).

Sykepleieren bør derfor fors $\varnothing$ ke å motivere de etterlatte til å være åpne om sine egne følelser og tanker. Åpenhet om selvmordet er viktig, da det gjør det mulig å sette ord på det som har skjedd.

\section{Samspillet med andre kan være vanskelig}

Uten åpenhet kan det som har skjedd, bli tildekket, noe som kan forlenge og komplisere sorgprosessen. Man stenger ute mennesker som kan være til hjelp, støtte og trøst fordi kommunikasjonen kan bli vanskelig (20).

Etterlatte i litteraturstudien beskrev at stigmatisering var en av grunnene til at de ikke ønsket å snakke om dødsårsaken til andre. Avvisende atferd fra venner de forventet skulle gi dem st $\varnothing$ tte, bidro til at de følte seg tilsidesatt og isolert i sorgarbeidet.

Samspillet mellom den som gir og den som får støtte, er ikke alltid like enkel og er ofte forbundet med konflikt, skuffelse, smerte og fortvilelse (20). 
Sykepleieren bør bidra til å gi informasjon til menneskene rundt de etterlatte, for eksempel om hvordan det er å være etterlatt etter selvmord, eller komme med råd om hvordan de kan henvende seg til den etterlatte uten å være for påtrengende. Informasjonen kan også inneholde fakta om selvmord og hva som er normale sorgreaksjoner.

\section{Sorggrupper er viktig for mestring}

Mange av de etterlatte i litteraturstudien deltok i støttegrupper hvor de kunne være seg selv og snakke om dødsfallet uten å være redd for andres reaksjoner. Støttegruppene var et tilfluktssted der de kunne føle seg akseptert og forstått, da de andre som deltok i gruppen, også hadde erfart å miste noen i selvmord.

De etterlatte beskrev st $\varnothing$ ttegruppene som et trygt sted hvor de kunne gjenfortelle historien sin og få en følelse av å høre til og få den støtten og omsorgen de hadde behov for (20). De etterlatte fikk muligheten til å anerkjenne sin egen sorg ved å snakke med andre etterlatte som var i et annet stadium i sorgen.

\section{$\equiv$ «Det å lytte aktivt er en av de viktigste og mest grunnleggende ferdighetene en sykepleier bør ha.»}

Sorggrupper er viktig for å oppleve mestring, læring og personlig vekst (20). Det å lytte aktivt er en av de viktigste og mest grunnleggende ferdighetene en sykepleier bør ha, og en måte å hjelpe etterlatte etter selvmord på.

Aktiv lytting er både personorientert og helsefremmende ved at man respekterer den andre som person og anerkjenner den andres selvbestemmelse (21).

Noen etterlatte foreldre i denne litteraturstudien mente at sorggruppene ikke fungerte for dem, da de erfarte at det var utfordrende å forholde seg til andres sorg i tillegg til sin egen. Selv om støttegrupper fungerer for mange etterlatte, skal man ikke utelukke at andre former for støtte også bør vurderes (20).

\section{Metodiske styrker og svakheter}


Det er en styrke at litteraturstudien kun omfatter funn fra vitenskapelige artikler som har benyttet kvalitativt design, noe som er egnet for å beskrive etterlattes erfaringer etter selvmord. Nordtvedt og medarbeidere (26) anbefaler å inkludere kvalitative artikler når man skal beskrive subjektive erfaringer og opplevelser.

Et av kriteriene i litteraturstudien var å inkludere forskningsartikler som var publisert de siste ti årene. Vi vurderer det som en styrke at artiklene er publisert etter 2014, noe som $\varnothing$ ker relevansen for dagens sykepleiepraksis.

De inkluderte artiklene i litteraturstudien ble gjennomført i vestlige land som Australia, England, Irland og USA. Likevel kan det være sannsynlig at funnene i disse studiene ikke direkte kan overføres til en norsk kontekst, da helsetjenestene i land som USA og Australia kan være annerledes enn i Norge.

Resultatet kan også være preget av konteksten rundt deltakerne siden det kan være store sosiale forskjeller $i$ samfunnet de lever i. Det mener vi kan være en svakhet i denne litteraturstudien.

Det at vi kun brukte to databaser i de systematiske søkene, kan sees på som en svakhet, da vi kan ha gått glipp av relevante artikler $i$ andre databaser.

Noen av funnene i litteraturstudien kan vurderes som svakere enn andre ved at de kun er hentet fra én, to eller tre studier. Vi ser likevel disse funnene som viktige for å beskrive mangfold og ulikheter i erfaringene de etterlatte hadde i de ulike studiene.

\section{Konklusjon}

Studiens hensikt var å beskrive etterlattes erfaringer etter å ha mistet noen i selvmord. Funnene i studien viser at etterlatte hadde behov for støtte og oppfølging av profesjonelt helsepersonell, men de erfarte at det var utfordrende å ta kontakt med hjelpeapparatet på grunn av fysiske og psykiske helseplager. 
Selv om mange etterlatte fikk god støtte fra sykepleiere, var det også flere som erfarte det motsatte. Enorm smerte og sorg fikk etterlatte til å skjule sine egne tanker og følelser fra venner, familie og samfunnet, og de nedprioriterte sine egne behov i sorgarbeidet. Stigmatisering var også en sentral årsak til at etterlatte hadde utfordringer med å snakke om selvmordet.

De fleste etterlatte hadde godt utbytte av å delta i st $\varnothing$ ttegrupper for selvmordsetterlatte, da de kunne snakke om selvmordet uten å være redd for negative reaksjoner. Likevel følte noen av dem at gruppene manglet en gruppeleder med tilstrekkelig kompetanse.

\section{Referanser}

1. Verdens helseorganisasjon (WHO). Suicide data. Verdens helseorganisasjon. Tilgjengelig fra:

https://www.who.int/mental_health/prevention/suicide/suicid eprevent/en/ (nedlastet 22.03.2020).

2. Folkehelseinstituttet. Selvmord i Norge. Oslo: Folkehelseinstituttet; 2020. Tilgjengelig fra: https://www.fhi.no/nettpub/hin/psykisk-helse/selvmord-inorge (nedlastet 24.04.2020).

3. Helsedirektoratet. Etter selvmordet - Veileder om ivaretakelse av etterlatte ved selvmord. Oslo: Helsedirektoratet; 2011. Tilgjengelig fra: https://www.helsedirektoratet.no/veiledere/ivaretakelse-avetterlatte-ved-selvmord/ (nedlastet 22.06.2020).

4. Dyregrov K, Plyhn E, Dieserud G. Etter selvmordet veien videre. Oslo: Abstrakt Forlag; 2009.

5. Hanschmidt F, Lehnig F, Riedel-Heller SG, Kersting A. The Stigma of suicide survivorship and related consequences - a systematic review. PLoS One. 2016;11(9). DOI: $\underline{10.1371 / \text { journal.pone.0162688 }}$

6. Forsberg C, Wengström Y. At göra systematiska litteraturstudier: värdering, analys och presentation av omvårdnadsforskning. 3 utg. Stockholm: Natur \& Kultur; 2013.

7. Helsebiblioteket. Sjekklister. Oslo: Helsebiblioteket; 2016. Tilgjengelig fra: https://www.helsebiblioteket.no/kunnskapsbasertpraksis/kritisk-vurdering/sjekklister (nedlastet 29.03.2020). 
8. Helsebiblioteket. Kritisk vurdering. Oslo:

Helsebiblioteket; 2020. Tilgjengelig fra:

https://www.helsebiblioteket.no/kunnskapsbasert-

praksis/kritisk-vurdering (nedlastet 28.03.2 020).

9. Evans D. Systematic reviews of interpretive research: interpretive data synthesis of processed data. Australian Journal of Advanced Nursing. 2002;20(2):22-6.

10. McKinnon JM, Chonody J. Exploring the formal supports used by people bereaved through suicide: a qualitative study. Social Work in Mental Health. 2014;12(3):231-48. DOI: 10.1080/15332985.2014.889637

11. Peters K, Cunningham C, Murphy G, Jackson D. Helpful and unhelpful responses after suicide: experiences of bereaved family members. International Journal of Mental Health Nursing. 2016;25(5):418-25. DOI: 10.1111/inm.12224

12. Wainwright V, Cordingley L, Chew- Graham CA, Kapur N, Shaw J, Smith S, McGale B, McDonnell S. Experiences of support from primary care and perceived needs of parents bereaved by suicide: a qualitative study. British Journal of General Practice. 2020;70(691):102-10. DOI:

10.3399/bjgp20X707849

13. Pitman A, De Souza T, Putri AK, Stevenson F, King M, Osborn D, Morant N. Support needs and experiences of people bereaved by suicide: qualitative findings from a crosssectional British study of bereaved young adults. International Journal of Environmental Research and Public Health. 2018;15(4):666. DOI: 10.3390/ijerph15040666

14. Sugrue JL, McGilloway S, Keegan O. The experiences of mothers bereaved by suicide: an exploratory study. Death Studies. 2014;38(2):118-24. DOI: 10.1080/07481187.2012.738765

15. Ross V, Kôlves K, Kunde L, De Leo D.

Parents' experiences of suicide-bereavement: a qualitative study at 6 and 12 months after loss. Int. J. Environ. Res. Public Health. 2018;15(4):618. DOI: 10.3390/ijerph15040618

16. Pitman AL, Stevenson F, Osborn DPJ, King MB. The stigma associated with bereavement by suicide and other sudden deaths: a qualitative interview study. Social Science and Medicine. 2018;198:121-9. DOI:

10.1016/j.socscimed.2017.12.035 
17. Peters K, Cunningham C, Murphy G, Jackson D. People look down on you when you tell them how he died: qualitative insights into stigma as experienced by suicide survivors. International Journal of Mental Health Nursing. 2016;25(3):251-7. DOI: 10.1111/inm.12210

18. Sheehan L, Corrigan PW, Al-Khouja MA, Lewy SA, Major DR, Mead J, Redmon M et al. Behind closed doors: the stigma of suicide loss survivors. OMEGA - Journal of Death and Dying. 2018;77(4):330-349. DOI:

$\underline{10.1177 / 0030222816674215}$

19. Shields C, Russo K, Kavanagh M. Angels of Courage: the experiences of mothers who have been bereaved by suicide. OMEGA - Journal of Death and Dying. 2017;80(2):175-201. DOI: $10.1177 / 0030222817725180$

20. Dyregrov A, Dyregrov K. Mestring av sorg: håndbok for etterlatte og hjelpere. Bergen: Forlaget Vigmostad \& Bjørke; 2017.

21. Helgesen LA. Menneskets dimensjoner: lærebok i psykologi. 3. utg. Oslo: Cappelen Damm Akademisk; 2017.

22. Helsepersonelloven: lov av 2 juli $199 \mathrm{nr} .64$ om helsepersonell mv. Oslo: Fagbokforlaget Vigmostad \& Bjørke; 2014 .

23. Kristoffersen NJ. Sykepleiefagets teoretiske utvikling. I: Kristoffersen NJ, Nortvedt F, Skaug EA, GH Grimsbø GH, red. Grunnleggende sykepleie bind 3: pasientfenomener, samfunn og mestring. 3. utg. Oslo: Gyldendal Akademisk; 2016. s. 1576.

24. Helse- og omsorgsdepartementet. Mestre hele livet: regjeringens strategi for god psykisk helse (2017-2022). Oslo: Helse- og omsorgsdepartementet; 2017. Tilgjengelig fra: https://www.regjeringen.no/no/dokumenter/mestre-helelivet/id2568354/ (nedlastet 22.04.2020).

25. Kristoffersen NJ, Breieevne G, Nortvedt F. Lidelse, mening og håp. I: Kristoffersen NJ, Nortvedt F, Skaug EA, red. Grunnleggende sykepleie bind 3: pasientfenomener og livsutfordringer. 2. utg. Oslo: Gyldendal Akademisk; 2015. s. $245^{-80}$. 
26. Nordtvedt MW, Jamtvedt G, Graverholt B, Nordheim

LV, Reinar LM. Jobb Kunnskapsbasert! En arbeidsbok. Oslo:

Cappelen Damm Akademisk; 2012. 